\title{
Effect of different traditional thermal processing methods on the nutritional and anti-nutritional composition of the marginalized indigenous mung bean (Vigna radiata)
}

\author{
${ }_{1,2, *}{ }^{*}$ Adeoye, J.K. and ${ }^{2}$ Oyetayo, V.O. \\ ${ }^{1}$ Department of Microbiology and Biochemistry, University of Fort Hare, Private Bag X1314, Alice, \\ South Africa \\ ${ }^{2}$ Federal University of Technology, PMB 704, Akure, Ondo State, Nigeria
}

\begin{abstract}
Article history:
December 2020

Available Online: 26

September 2021

\section{Keywords:}

Plant protein,

Chemical properties,

Fermentation,

Leguminous,

Protein,

Food processing
\end{abstract}

Received:8 November 2020

Received in revised form: 11

Accepted: 16 February 2021

DOI:

https://doi.org/10.26656/fr.2017.5(5).103

\begin{abstract}
In the present study, the effects of fermentation, roasting, boiling, and boiling with potash on the nutritional and anti-nutritional composition of unsprouted mung bean seed was investigated. Mung bean (Vigna radiata), an underutilized bean was subjected to different processing methods such as boiling, boiling with potash, roasting, and fermentation. Chemical properties such as proximate, mineral, amino acid, and anti-nutrient analyses were done. A total of seventeen amino acids were assayed in mung bean subjected to different processing methods. The ordinary boiling method had the most significant $(\mathrm{P}<0.05)$ retention in the amino acid content of mung bean seed. The result of the statistical analysis revealed that there was no significant increase $(P>0.005)$ in the glutamic acid content of mung bean subjected to different processing methods. Fermentation slightly increased the protein content from 25.45 to $25.70 \%$, while the roasted sample had the lowest protein content of $22.15 \%$. There was a fluctuation in the mineral content of processed mung bean. Roasting significantly increased the antinutritional (tannin) content from 0.057 to $0.094 \mathrm{mg} / \mathrm{g}$, while saponin was reduced significantly from 35.73 to $6.67 \mathrm{mg} / \mathrm{g}$. This study has shown that mung bean is on average high in protein content which can serve as a good supplement for dietary protein. Moreover, fermentation and boiling methods may better enhance the nutritional composition of mung bean in terms of retention of protein and reduction of antinutritional factors.
\end{abstract}

\section{Introduction}

There is an urgent need in developing/poor countries for alternative sources of food that would be affordable and also be rich in essential nutrients and energy to meet the food demand of the increasing population (Hossain et al., 2016; César et al., 2019). Interests in this regard are being redirected towards several leguminous proteins which may account for about $80 \%$ of dietary protein and have also provided a viable economic alternative for the supplementation of the animal protein (Famurewa and Raji, 2005; Hossain et al., 2016). Leguminous proteins are mostly consumed where consumption of animal protein may be limited because of either cultural or religious, economic, social factors (Esenwah and Ikenebomeh, 2008). They may be eaten as meals when cooked or used commonly as condiments in their fermented form to enhance the flavours of foods (Oniofiok et al., 1996; Achi., 2005)
Legume processing involves techniques for converting raw materials into finished and semi-finished products ready for consumption or storage (Ihekoronye and Ngoddy, 1985). This encompasses a wide range of techniques including fermenting, preserving with salt, sun drying and various types of cooking such as smoking, roasting, steaming, and oven baking (Fasoyiro et al., 2012). Benefits of processing food include toxin removal, preservation, easy distribution and marketing, increased food consistency, increased year-round availability of many foods, inactivation, or destruction of heat-labile antinutritional factors among others (Chau et al., 1997; Wang et al., 1997; Vijayakumari et al., 1998; Fasoyiro et al., 2012)

Mung bean is a legume cultivated in many tropical African countries, it is a principal cash crop in some parts (Lambrides and Godwin, 2006; Motgotsi, 2006). This legume has been successfully introduced and grown 
in some Southern parts of Nigeria (Agugo, 2006). It has globose, white hilum glossy seeds. The seeds are small, ovoid and mostly green, but could also show other colours (Adeoye et al., 2020). It can be processed in various ways such as roasting, boiling (until it is soft to eat), processed into flour, or processed to make starch noodles. The dried mature seed is cooked and consumed either alone or in combination with starchy staples (John and Oyetayo, 2016). However, antinutritional factors can limit the use of mung bean. It was reported that legumes are often cooked before their use in the human diet. This helps to improve protein quality by destruction or inactivation of heat-labile antinutritional factors (Chau et al., 1997; Wang et al., 1997; Vijayakumari et al., 1998).

Recent claims about the nutritional content of sprouted mung bean seeds have aroused global interest in mung beans. In the present study, the effect of fermentation, roasting, boiling, and boiling with potash on the nutritional and antinutritional composition of unsprouted mung bean seed was investigated.

\section{Materials and methods}

\subsection{Sample collection}

Mung bean (Vigna radiata) seeds used for this study were obtained from Igasi Akoko, in Akoko North West Local Government Area of Ondo State, Nigeria. These materials were identified and authenticated at the Department of Crop Soil and Pest Management of the Federal University of Technology, Akure and were taken to the microbiology laboratory for analysis. The seed was sorted to remove extraneous matters.

\subsection{Processing of mung bean seed}

Mung bean samples were divided into five portions (A, B, C, D, and E) of $500 \mathrm{~g}$ each using an electronic weighing balance (Electronic Balance, MT-301 Model) and were washed in clean tap water before processing.

\subsubsection{Boiling}

Sample A $(500 \mathrm{~g})$ was boiled in tap water $(1: 8 \mathrm{w} / \mathrm{v})$ at $100^{\circ} \mathrm{C}$ on Gallenkamp thermostat hot plate (HPL-500$50 \mathrm{M}$ ) for $3 \mathrm{hrs}$ and 20 mins until they become very soft when felt between fingers.

\subsubsection{Boil with potash}

Potash (2.63 g) was added to $500 \mathrm{~g}$ (sample B) and was cooked in tap water $(1: 8 \mathrm{w} / \mathrm{v})$ at $100^{\circ} \mathrm{C}$ for $2 \mathrm{hrs} 40$ min on Gallenkamp thermostat hot plate (HPL-500-50 M) until they become soft when felt between fingers.

\subsubsection{Roasting}

The third portion $\mathrm{C}(500 \mathrm{~g})$ was roasted using a hotbox oven (Heating Drying Oven DHG Model) at a temperature of $120^{\circ} \mathrm{C}$ for $2 \mathrm{hrs}$.

\subsubsection{Fermentation}

A $500 \mathrm{~g}$ of sample D was left to ferment in $1.5 \mathrm{~L}$ of sterile distilled water for seven days at ambient temperature in a covered plastic bowl.

Sample E $(500 \mathrm{~g})$ which serves as the control was analysed raw. The processing flow chart is shown in Figure 1.

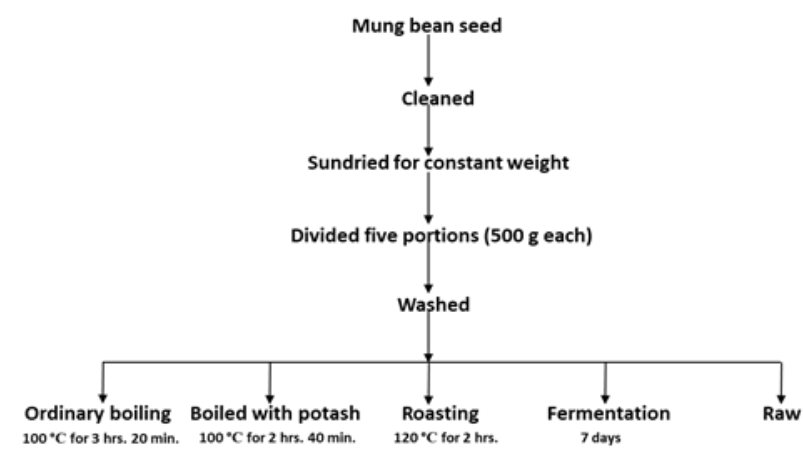

Figure 1. Mung bean processing flow chart

\subsection{Chemical analysis}

The samples subjected to fermentation, boiling, and boiling with potash, were oven-dried before chemical analyses were carried out on them. The analyses were done in triplicates.

\subsubsection{Determination of proximate content}

Estimates made of nitrogen as an index of crude protein, moisture, ash, fat, and crude fibre were done according to the method of (AOAC, 2000). The carbohydrate contents of the samples were determined when these parameters were subtracted from $100 \mathrm{viz}$ : \% Carbohydrate $=100-(\%$ Ash $+\%$ Protein $+\%$ Fat $+\%$ Fibre $+\%$ Moisture) .

\subsubsection{Mineral composition}

Minerals such as (Calcium, Potassium, Sodium, Magnesium, Iron, Zinc, Phosphorus, Copper, and Manganese) were assayed by wet ashing method for each sample, followed by reading the level of mineral using a spectrophotometer. Atomic absorption spectrophotometer (Buck 201, VGP) was used in determining the mineral content (AOAC, 2002). Mineral content was calculated thus:

$$
\text { Mineral }(\mathrm{mg} / 100 \mathrm{~g})=\mathrm{R} \times \mathrm{V} \times \mathrm{D} / \mathrm{Wt} \text {. }
$$

Where $\mathrm{V}=$ Volume of sample digested, $\mathrm{R}=$ Solution 
concentration, $\mathrm{Wt}=$ Weight of sample and $\mathrm{D}=$ Dilution factor.

\subsubsection{Determination of amino acids}

Four stages were involved in the determination of the amino acid composition of mung bean samples using the method described by (Benitez, 1989; AOAC, 2006). About $5 \mathrm{~g}$ of the samples were dried to constant weight, hydrolysed, defatted, evaporated using a rotary evaporator and loaded into a Sequential Multi-Sample Amino Acid Analyzer (TSM). The quantity of each amino acid present in the sample was calculated in $\mathrm{g} / 100$ $\mathrm{g}$ or $\mathrm{g} / 16 \mathrm{~N}$ protein by this formula:

Concentration of amino acid $(\mathrm{g} / 100 \mathrm{~g}$ protein $)=\mathrm{NH} \times \mathrm{W}$ at $\mathrm{NH} / 2 \times \mathrm{Sstd} \times \mathrm{C}$

where $\mathrm{C}=$ Dilution $\times 16 /$ Sample weight $(\mathrm{g}) \times \mathrm{N} \% \times$ 10 vol. loaded divided by $\mathrm{NH} \times \mathrm{W}$ (nleu)

where $\mathrm{W}=$ Width at half-height, $\mathrm{NH}=$ Net height and Nleu $=$ Norleucin.

The Norleucine equivalent (NE) of each amino acid present in the standard mixture was calculated by the formula:

$\mathrm{NE}=$ Area of Norleucine peak / Area of each amino acid

A constant "S std" was calculated for each amino acid in the standard mixture.

S std $=$ NE std $\times$ Molecular Weight $\times \mu$ Moles Amino Acid std

\subsubsection{Determination of antinutrients}

\subsubsection{Trypsin inhibitor activity (TIA)}

Trypsin inhibitor activity was done using the procedure by (Kakade et al., 1974). Each dilution of the sample was used with BAPNA substrate and trypsin solution as described by (Kakade et al., 1974) at $37^{\circ} \mathrm{C}$. The reaction was allowed to take place in a water bath for $10 \mathrm{~min}$ and their absorbance read at $410 \mathrm{~nm}$ against each sample blank.

\subsubsection{Extraction of trypsin from samples}

About $1.0 \mathrm{~g}$ of finely ground and sieved samples of the seed flour was defatted for $3 \mathrm{hrs}$ using n-hexane. The sample was mixed with $50 \mathrm{~mL}$ of $0.01 \mathrm{M} \mathrm{NaOH}$, and the $\mathrm{pH}$ was adjusted to 9.5 using $0.1 \mathrm{M} \mathrm{NaOH}$ or $0.1 \mathrm{M} \mathrm{HCl}$. The mixture was left for $10 \mathrm{~min}$ at $1,000 \mathrm{rpm}$. The extract from each sample was diluted with distilled water to a dilution whereby $1 \mathrm{~mL}$ extract produced trypsin inhibition activity of between 40 and $60 \%$.

\subsubsection{Tannin determination}

Tannin's determination was done using the method described by (Makkar and GoodChild, 1996). The absorbance was read at $725 \mathrm{~nm}$ using AJ-C03 Spectrophotometer against a reagent blank concentration of the same solution from a standard tannic acid curve that was prepared.

Tannic acid per $\mathrm{mL}$ of extract $=\mathrm{R} \times 1000 /$ volume of sample used $(\mathrm{mL})$

where $\mathrm{R}=$ result read from the standard tannin acid solution curve.

\subsubsection{Determination of phytate}

Phytate determination was done according to the method of (Wheeler and Ferrel, 1971). About $4 \mathrm{~g}$ samples were soaked in $100 \mathrm{~mL}$ of $2 \% \mathrm{HCl}$ for $3 \mathrm{hrs}$ and then filtered through a Whatman No. 1 filter paper. About $25 \mathrm{~mL}$ was taken out of the filtrate and placed inside a conical flask and $5 \mathrm{~mL}$ of $0.3 \%$ of ammonium thiocyanate solution was added as an indicator. After which, $53.5 \mathrm{~mL}$ of distilled water was added for proper acidity, and this was titrated against $0.00566 \mathrm{~g} / \mathrm{mL}$ of standard iron (iii) chloride solution that contains about $0.00195 \mathrm{~g}$ of iron $/ \mathrm{mL}$ until a brownish-yellow colouration persists for $5 \mathrm{~min}$.

Phytate $=$ Titre value $\times 1.19 \times 3.55 \mathrm{mg} / \mathrm{g}$

\subsubsection{Determination of saponin}

The spectrophotometric method of (Brunner et al., 1984) was used for Saponin determination. The absorbance was read against the blank at $380 \mathrm{~nm}$ using AJ-C03 Spectrophotometer.

\subsection{Statistical analysis}

All data were statistically analysed by one-way analysis of variance (ANOVA) and means were separated by Duncan's Multiple Range Test (SPSS 16.0 version). Differences were considered significant at $\mathrm{P}<0.05$.

\section{Results and discussion}

The result of the proximate composition (Table 1) revealed that there were differences $(\mathrm{P}<0.05)$ in the moisture contents of the samples processed by different processing methods. The moisture content of the raw sample was $4.81 \%$. There was an increase in the moisture content of boiled, boiled with potash and fermented samples from 4.81 to $7.30,8.59$ and $8.94 \%$, respectively. The roasted sample had the lowest moisture content of $3.72 \%$. This might be a result of a loss of moisture during the application of dry heat during roasting. This agrees with the work of Ndidi et al. (2014) on the effects of processing (boiling and roasting) on the 
Table 1. Proximate composition of processed and unprocessed mung bean

\begin{tabular}{lccccc}
\hline \multirow{2}{*}{ Proximate composition (\%) } & \multicolumn{5}{c}{ Processing methods } \\
\cline { 2 - 6 } & Boiling & Boiled with Potash & Roasting & Fermentation & Raw \\
\hline Moisture content & $7.30 \pm 0.01^{\mathrm{c}}$ & $8.59 \pm 0.12^{\mathrm{d}}$ & $3.72 \pm 0.90^{\mathrm{a}}$ & $8.94 \pm 0.45^{\mathrm{e}}$ & $4.81 \pm 0.01^{\mathrm{b}}$ \\
Crude fibre & $1.83 \pm 0.17^{\mathrm{ab}}$ & $2.40 \pm 0.30^{\mathrm{c}}$ & $2.47 \pm 0.20^{\mathrm{c}}$ & $1.61 \pm 0.01^{\mathrm{a}}$ & $2.06 \pm 0.11^{\mathrm{a}}$ \\
Ash content & $3.04 \pm 0.50^{\mathrm{b}}$ & $3.30 \pm 0.55^{\mathrm{c}}$ & $4.14 \pm 0.60^{\mathrm{e}}$ & $2.02 \pm 0.45^{\mathrm{a}}$ & $3.59 \pm 0.01^{\mathrm{d}}$ \\
Crude fat & $11.31 \pm 0.35^{\mathrm{c}}$ & $6.09 \pm 0.01^{\mathrm{a}}$ & $8.56 \pm 0.18^{\mathrm{b}}$ & $12.77 \pm 0.01^{\mathrm{e}}$ & $12.13 \pm 0.26^{\mathrm{d}}$ \\
Crude protein & $24.08 \pm 0.01^{\mathrm{c}}$ & $23.46 \pm 0.01^{\mathrm{b}}$ & $22.15 \pm 0.49^{\mathrm{a}}$ & $25.70 \pm 0.40^{\mathrm{d}}$ & $25.45 \pm 0.01^{\mathrm{d}}$ \\
Carbohydrate content & $52.44 \pm 0.10^{\mathrm{c}}$ & $56.16 \pm 0.01^{\mathrm{d}}$ & $58.96 \pm 0.01^{\mathrm{e}}$ & $49.48 \pm 0.01^{\mathrm{a}}$ & $51.96 \pm 0.01^{\mathrm{b}}$ \\
\hline
\end{tabular}

Values are expressed as mean \pm SD $(n=3)$. Values with the same superscript letters with the same row are not significantly different $(\mathrm{P}>0.05)$.

nutritional and antinutritional properties of Bambara groundnuts (Vigna subterranea [L.] Verdc.) from Southern Kaduna, Nigeria. The highest moisture content observed in the fermented sample could be a result of the absorption of free water during fermentation. There were no significant $(p>0.05)$ differences in the crude fibre and ash content of processed samples which is often an important dietary composition (Nugraheni et al., 2020). This agreed with the observation reported by (Mubarak, 2005) for mung beans as affected by some home traditional processes, while fermentation reduced the ash content to $2.02 \%$. The reduction might be attributed to the fermentative activities of the fermenting microbes. Roasting and boiling with potash had a more significant reduction in lipid content than roasting. The significant reduction in crude fat observed in the roasted sample might be a result of the application of dry heat during processing (Ndidi et al., 2014). Also, a reduction $(p<0.05)$ of the crude fat content of the sample boiled with potash $(6.09 \%)$ could be because of the addition of potash during processing. The protein content of the raw sample was $25.45 \%$. This is close to $27.5 \%$ reported by Mubarak (2005). The roasted sample had the lowest protein value of $22.1 \%$, while the sample boiled with potash had a value of $23.46 \%$. There were no significant differences $(p>0.05)$ in the total protein contents in the sample processed by ordinary boiling, boiling with potash and roasting. Fermentation only, slightly increased the protein content from 25.45 to $25.63 \%$ which could be attributed to the proteolytic activities of the fermenting microbial population (John and Oyetayo, 2016; Hao et al., 2020). However, the insignificant increase in the protein content of the fermented sample may be due to the considerable loss of nutrient to the free water during fermentation (Malomo et al., 2015).

The mineral composition of the processed mung bean changed during processing (Table 2). There was a significant difference $(p<0.05)$ in the potassium content of mung bean subjected to different processing methods. Reduction $(p<0.05)$ in potassium content of samples processed by boiling and boiling with potash and no significant increase $(p>0.05)$ in sodium, calcium, magnesium, copper, and manganese content of mung bean subjected to different processing methods. However, each of the processing methods slightly increased in zinc, iron, and phosphorus content of the processed samples. Differences observed in the mineral content of the sample processed by roasting could be attributed to the dry heat applied during processing. (Haytowitz and Mathews, 1983) had earlier reported that cooking in boiling water caused a great loss of K (24\%) and $\mathrm{Fe}(8 \%)$, while a loss of $22 \%$ of $\mathrm{Mg}$ from mature cowpeas when cooked by autoclaving. Salama and Ragab (1997) reported that kidney beans cooked using conventional and microwave methods had different retention rates of minerals. These results agree with those reported by (Khalil, 2001) for guar and faba beans. Generally, the decrease in mineral contents of boiled samples may be due to leaching out during boiling

Table 2. Mineral composition of processed and unprocessed mung bean

\begin{tabular}{cccccc}
\hline \multirow{2}{*}{ Minerals (mg/g) } & \multicolumn{5}{c}{ Processing methods } \\
\cline { 2 - 6 } & Boiling & Boiled with Potash & Roasting & Fermentation & Raw \\
\hline Potassium & $15.65 \pm 0.01^{\mathrm{b}}$ & $6.17 \pm 0.17^{\mathrm{a}}$ & $16.68 \pm 0.01^{\mathrm{c}}$ & $25.77 \pm 0.01^{\mathrm{e}}$ & $17.24 \pm 0.01^{\mathrm{d}}$ \\
Sodium & $2.64 \pm 0.12^{\mathrm{b}}$ & $2.40 \pm 0.40^{\mathrm{ab}}$ & $2.43 \pm 0.43^{\mathrm{ab}}$ & $1.95 \pm 0.45^{\mathrm{a}}$ & $2.68 \pm 0.01^{\mathrm{ab}}$ \\
Calcium & $2.29 \pm 0.29^{\mathrm{a}}$ & $2.74 \pm 0.24^{\mathrm{b}}$ & $2.01 \pm 0.10^{\mathrm{a}}$ & $3.27 \pm 0.27^{\mathrm{c}}$ & $2.37 \pm 0.01^{\mathrm{a}}$ \\
Magnesium & $0.54 \pm 0.40^{\mathrm{a}}$ & $0.78 \pm 0.50^{\mathrm{b}}$ & $0.50 \pm 10^{\mathrm{a}}$ & $0.60 \pm 0.10^{\mathrm{a}}$ & $0.59 \pm 0.95^{\mathrm{a}}$ \\
Zinc & $0.74 \pm 0.40^{\mathrm{a}}$ & $0.74 \pm 0.20^{\mathrm{a}}$ & $0.75 \pm 0.50^{\mathrm{a}}$ & $0.79 \pm 0.90^{\mathrm{a}}$ & $0.73 \pm 0.01^{\mathrm{a}}$ \\
Iron & $0.94 \pm 0.40^{\mathrm{c}}$ & $0.70 \pm 0.10^{\mathrm{ab}}$ & $0.77 \pm 0.70^{\mathrm{b}}$ & $0.72 \pm 0.20^{\mathrm{ab}}$ & $0.65 \pm 0.01^{\mathrm{a}}$ \\
Phosphorus & $4.66 \pm 0.01^{\mathrm{b}}$ & $3.91 \pm 0.81^{\mathrm{b}}$ & $5.75 \pm 0.75^{\mathrm{c}}$ & $2.66 \pm 0.66^{\mathrm{a}}$ & $3.83 \pm 0.01^{\mathrm{b}}$ \\
Copper & $0.020 \pm 0.10^{\mathrm{c}}$ & $0.02 \pm 0.01^{\mathrm{c}}$ & $0.00 \pm 0.00^{\mathrm{a}}$ & $0.02 \pm 0.01^{\mathrm{c}}$ & $0.01 \pm 0.01^{\mathrm{b}}$ \\
Manganese & $0.21 \pm 0.10^{\mathrm{b}}$ & $0.20 \pm 0.50^{\mathrm{b}}$ & $0.23 \pm 0.30^{\mathrm{b}}$ & $0.12 \pm 0.10^{\mathrm{a}}$ & $0.23 \pm 0.00^{\mathrm{b}}$ \\
\hline
\end{tabular}

Values are expressed as mean $\pm \mathrm{SD}(\mathrm{n}=3)$. Values with the same superscript letters with the same row are not significantly different $(\mathrm{P}>0.05)$. 
processes. These data are in the same trend as the report of (Mubarak, 2005) and the work of (Mansour and ElAdawy, 1994) on boiled fenugreek seeds.

There were fluctuations in the amino acid contents of the mung bean samples subjected to different processing methods (Tables 3 and 4). However, each of the processing methods had a slight increase and decrease in the amino acid content of the processed samples. All processing methods slightly increased the concentration of glutamic acid, glycine, and a slight reduction in serine, proline, cysteine, and isoleucine. All processing methods slightly increased the concentration of leucine (except the fermentation process). Also, there was a slight increase in the concentration of threonine by fermentation and roasting, these agree with the work of (Mubarak, 2005).

All processing methods were able to achieve a reduction in the antinutrient contents of mung bean seed (Table 5). Fermentation and roasting were the most effective processing methods that revealed a significant reduction $(p<0.05)$ in the antinutrient contents of the samples. Saponin and trypsin inhibitor activities were significantly $(p<0.05)$ reduced by fermentation and roasting processes. The reduction in phytic acid and trypsin inhibitor by fermentation agrees with the work of (Mubarak, 2005) and (Oyarekua, 2011). None of the processing methods further reduced the tannin content of the samples, but an increase was observed from 0.57 to 0.94 in the sample processed by boiling with potash. This could be attributed to the effect of potash in conjunction with thermal effect during processing and this agrees with the report of Arinola and Adesina (2014).

Table 3. Essential amino acid in raw and processed mung bean samples

\begin{tabular}{cccccc}
\hline \multirow{2}{*}{$\begin{array}{c}\text { Amino Acid } \\
(\mathrm{g} / 100 \mathrm{~g})\end{array}$} & Boiling & Boiled with Potash & Roasting & Fermentation & Raw \\
\cline { 2 - 5 } & $5.24 \pm 0.24^{\mathrm{a}}$ & $5.08 \pm 0.80^{\mathrm{a}}$ & $6.97 \pm 0.01^{\mathrm{b}}$ & $6.97 \pm 0.01^{\mathrm{c}}$ & $6.75 \pm 0.50^{\mathrm{c}}$ \\
Lysine & $3.09 \pm 0.09^{\mathrm{b}}$ & $2.84 \pm 0.40^{\mathrm{a}}$ & $4.08 \pm 0.80^{\mathrm{d}}$ & $4.08 \pm 0.01^{\mathrm{d}}$ & $3.53 \pm 0.30^{\mathrm{c}}$ \\
Threonine & $3.47 \pm 0.70^{\mathrm{c}}$ & $3.10 \pm 0.10^{\mathrm{b}}$ & $2.59 \pm 0.01^{\mathrm{a}}$ & $2.59 \pm 0.90^{\mathrm{a}}$ & $3.00 \pm 0.10^{\mathrm{b}}$ \\
Histidine & $4.71 \pm 0.5^{\mathrm{c}}$ & $3.30 \pm 0.30^{\mathrm{a}}$ & $3.85 \pm 0.01^{\mathrm{b}}$ & $3.86 \pm 0.02^{\mathrm{b}}$ & $4.44 \pm 0.01^{\mathrm{c}}$ \\
Valine & $1.72 \pm 0.12^{\mathrm{c}}$ & $1.41 \pm 0.11^{\mathrm{b}}$ & $1.02 \pm 0.70^{\mathrm{a}}$ & $1.02 \pm 0.12^{\mathrm{a}}$ & $1.25 \pm 0.20^{\mathrm{ab}}$ \\
Methionine & $3.53 \pm 0.23^{\mathrm{c}}$ & $3.30 \pm 0.01^{\mathrm{b}}$ & $2.55 \pm 0.02^{\mathrm{a}}$ & $2.55 \pm 0.02^{\mathrm{a}}$ & $3.81 \pm 0.11^{\mathrm{d}}$ \\
Isoleucine & $8.68 \pm 0.01^{\mathrm{c}}$ & $8.00 \pm 0.01^{\mathrm{b}}$ & $8.20 \pm 0.01^{\mathrm{b}}$ & $7.21 \pm 0.21^{\mathrm{a}}$ & $7.90 \pm 0.50^{\mathrm{b}}$ \\
Leucine & $5.40 \pm 0.20^{\mathrm{c}}$ & $5.15 \pm 0.01^{\mathrm{b}}$ & $4.60 \pm 0.00^{\mathrm{a}}$ & $4.55 \pm 0.50^{\mathrm{a}}$ & $5.00 \pm 0.01^{\mathrm{f}}$ \\
\hline Phenylalanine & &
\end{tabular}

Values are expressed as mean \pm SD $(n=3)$. Values with the same superscript letters with the same row are not significantly different $(\mathrm{P}>0.05)$.

Table 4. Non-essential amino acid in raw and processed mung bean

\begin{tabular}{|c|c|c|c|c|c|}
\hline \multirow{2}{*}{$\begin{array}{l}\text { Amino Acid } \\
(\mathrm{g} / 100 \mathrm{~g})\end{array}$} & \multicolumn{5}{|c|}{ Processing methods } \\
\hline & Boiling & Boiled with Potash & Roasting & Fermentation & Raw \\
\hline Arginine* & $7.61 \pm 0.19^{c}$ & $6.87 \pm 0.35^{\mathrm{b}}$ & $6.39 \pm 0.90^{\mathrm{a}}$ & $6.39 \pm 0.90^{\mathrm{a}}$ & $6.39 \pm 0.80^{\mathrm{a}}$ \\
\hline Aspartic acid & $9.15 \pm 0.50^{\mathrm{a}}$ & $9.55 \pm 0.50^{\mathrm{b}}$ & $12.22 \pm 0.25^{\mathrm{c}}$ & $12.25 \pm 0.15^{\mathrm{d}}$ & $10.61 \pm 0.11^{\mathrm{d}}$ \\
\hline Serine* & $4.40 \pm 0.20^{\mathrm{c}}$ & $3.99 \pm 0.20^{b}$ & $3.31 \pm 0.01^{\mathrm{a}}$ & $3.31 \pm 0.01^{\mathrm{a}}$ & $4.86 \pm 0.40^{\mathrm{d}}$ \\
\hline Glutamic acid & $17.20 \pm 1.00^{\mathrm{a}}$ & $16.00 \pm 1.00^{\mathrm{a}}$ & $16.21 \pm 0.21^{\mathrm{a}}$ & $16.21 \pm 1.01^{\mathrm{a}}$ & $15.68 \pm 1.18^{\mathrm{a}}$ \\
\hline Proline* & $2.03 \pm 0.13^{\mathrm{a}}$ & $3.05 \pm 0.15^{\mathrm{c}}$ & $2.44 \pm 0.34^{\mathrm{b}}$ & $2.44 \pm 0.14^{\mathrm{b}}$ & $3.66 \pm 0.01^{\mathrm{d}}$ \\
\hline Glycine & $4.80 \pm 0.01^{\mathrm{b}}$ & $4.08 \pm 0.80^{\mathrm{ab}}$ & $4.32 \pm 0.32^{\mathrm{ab}}$ & $4.32 \pm 0.2^{\mathrm{ab}}$ & $3.70 \pm 0.70^{\mathrm{a}}$ \\
\hline Alanine & $5.010 .11^{\mathrm{b}}$ & $4.00 \pm 0.02^{\mathrm{a}}$ & $4.79 \pm 0.19^{\mathrm{b}}$ & $4.81 \pm 0.15^{\mathrm{b}}$ & $4.18 \pm 0.01^{\mathrm{a}}$ \\
\hline Cystine* & $1.19 \pm 0.19^{\mathrm{b}}$ & $0.93 \pm 0.30^{\mathrm{a}}$ & $0.73 \pm 0.01^{\mathrm{a}}$ & $0.73 \pm 0.30^{\mathrm{a}}$ & $1.32 \pm 0.22^{\mathrm{b}}$ \\
\hline Tyrosine* & $4.44 \pm 0.24^{\mathrm{c}}$ & $3.50 \pm 0.01^{\mathrm{b}}$ & $2.81 \pm 0.31^{\mathrm{a}}$ & $2.81 \pm 0.30^{\mathrm{a}}$ & $3.33 \pm 0.13^{\mathrm{b}}$ \\
\hline
\end{tabular}

Values are expressed as mean $\pm \mathrm{SD}(\mathrm{n}=3)$. Values with the same superscript letters with the same row are not significantly different $(\mathrm{P}>0.05)$.

Table 5. Antinutrient content of processed and unprocessed mung bean samples

\begin{tabular}{cccccc}
\hline Anti-nutrient & \multicolumn{5}{c}{ Processing methods } \\
\cline { 2 - 6 } content $(\mathrm{mg} / \mathrm{g})$ & Boiling & Boiled with Potash $^{\text {Roasting }}$ & Fermentation & Raw \\
\hline Phytic acid & $7.82 \pm 0.42^{\mathrm{c}}$ & $5.76 \pm 0.01^{\mathrm{b}}$ & $6.59 \pm 0.00^{\mathrm{b}}$ & $6.18 \pm 0.41^{\mathrm{ab}}$ & $7.83 \pm 0.42^{\mathrm{c}}$ \\
Tannin & $0.057 \pm 0.01^{\mathrm{a}}$ & $0.094 \pm 0.01^{\mathrm{b}}$ & $0.057 \pm 0.01^{\mathrm{a}}$ & $0.057 \pm 0.01^{\mathrm{a}}$ & $0.057 \pm 0.01^{\mathrm{a}}$ \\
Trypsin inhibitor & $48.77 \pm 0.01^{\mathrm{d}}$ & $34.15 \pm 0.01^{\mathrm{c}}$ & $29.47 \pm 0.01^{\mathrm{a}}$ & $32.44 \pm 0.01^{\mathrm{b}}$ & $65.68 \pm 0.50^{\mathrm{e}}$ \\
Saponin & $12.64 \pm 0.00^{\mathrm{d}}$ & $11.00 \pm 0.90^{\mathrm{c}}$ & $6.67 \pm 0.01^{\mathrm{a}}$ & $9.37 \pm 0.94^{\mathrm{b}}$ & $35.73 \pm 0.09^{\mathrm{e}}$ \\
\hline
\end{tabular}

Values are expressed as mean $\pm \mathrm{SD}(\mathrm{n}=3)$. Values with the same superscript letters with the same row are not significantly different $(\mathrm{P}>0.05)$. 


\section{Conclusion}

This study examined the effect of different processing methods on the nutritional and antinutritional properties of mung bean ( $V$. radiata). The results of the proximate analysis indicated that natural fermentation slightly increases the protein content with a reduction in the carbohydrate content of mung bean. The result of the mineral composition revealed that mung bean is a good source of mineral elements. It was found to be a good source of both essential and non-essential amino acids. The antinutrient content was reduced by fermentation. Fermentation and cooking could better enhance the nutritional composition of mung beans.

\section{Conflict of interests}

The authors declare no conflict of interest.

\section{References}

Arinola, S.O. and Adesina, K. (2014). Effect of thermal processing on the nutritional, antinutritional, and antioxidant properties of Tetracarpidium conophorum (African Walnut). Journal of Food Processing, 2014, 418380. https:// doi.org/10.1155/2014/418380

Achi, O.K. (2005). Traditional fermented protein condiments in Nigeria. African Journal of Biotechnology, 4(13), 1612-1621.

Adeoye, J.K., Adewole, S.A., Folasade, B.-O., Adebanke, A. and Olusegun, V.O. (2020). The phytochemical content and antimicrobial activity of mung bean (Vigna radiata) Extract against some selected pathogens of medical importance. World Journal of Advance Healthcare Research, 4(3), 147$155 . \quad$ https://www.wjahr.com/admin/assets/ article_issue/19042020/1589632093.pdf

John, K.A. and Olusegun, O.V. (2016). Effect of fermentation on the microbial, proximate and mineral composition of Mung Bean (Vigna radiata). Journal of Applied Life Sciences International, 5(4), 1-12. https://doi.org/10.9734/ JALSI/2016/25298

Agugo, B.A.C. (2003). Introducing mung bean into South-Eastern Nigeria's humid forest: Overview of potentials. Proceedings of the 37th annual conference of agricultural society of Nigeria. The University of Calabar, Nigeria.

Association of Official Analytical Chemists (AOAC). (2000). Official methods of analysis of AOAC International. 17th ed. Gaithersburg, USA: AOAC International,

Association of Official Analytical Chemists (AOAC). (2002). Official Methods of Analysis, $17^{\text {th }}$ ed.
Washington D.C., USA: Association of Official Analytical Chemists.

Association of Official Analytical Chemists (AOAC). (2006). Official methods of analysis, $18^{\text {th }}$ ed. Washington D.C., USA: Association of Official Analytical Chemists.

Benitez, L.V. (1989). Amino acid and fatty acid profiles in aquaculture nutrition studies. In Silva, D.D.S. (Ed.) Fish Nutrition Research in Asia: Proceedings of the Third Asian Fish Nutrition Network Meeting, p. 23-35. Manilla, Phillippines: Asian Fisheries Society.

Brunner, J.H. (1984). Direct spectrophotometer determination of saponin. Journal of Animal Science, 34, 1314-1326.

César, B., Mauricio, O., Traudy, W., Monserrat, S., Tamara, B. and Mariela, B. (2019). Chemical and Nutritional Evaluation of Protein-Rich Ingredients Obtained through a Technological Process from Yellow Lupin Seeds (Lupinus luteus). Plant Foods for Human Nutrition, 74(4), 509-517. https:// doi.org/10.1007/s11130-019-00768-0

Chau, C.F., Cheun, P.C. and Wong, Y.S. (1997). Effect of cooking on the content of amino acids and antinutrients in three Chinese indigenous legume seeds. Journal of the Science of Food and Agriculture, 75(4), 447-452. https://doi.org/10.1002/ (SICI)1097-0010(199712)75:4<447::AID-

JSFA896>3.0.CO;2-5

Esenwah, C.N. and Ikenebomeh, J.M. (2008). Processing effects on the Nutritional and Antinutritional contents of African locust bean (Parkia biglobosa Benth.) seed. Pakistan Journal of Nutrition, 7(2), 214-217. https://doi.org/10.3923/pjn.2008.214.217

Famurewa, J.A.V. and Raji, O.A. (2005). Parameters affecting milling qualities of undefeated soybeans (Glycine max, 1. Merill) (1) selected thermal treatment. International Journal of Food Engineering, 1 (4), 6. https://doi.org/10.2202/1556-3758.1026

Fasoyiro, S.B., Obatolu, V.A., Asaye, O.A., Adeojo, E.A. and Ogunleti, D.O. (2009). Chemical and Sensory qualities of Pigeon pea (Cajanus cajan) developed into a local spice "dawadawa" Nigerian Food Journal, 27(2), 150-158. https:// doi.org/10.4314/nifoj.v27i2.47485

Furst, P. and Stehle, P. (2004). What are the essential elements needed for the determination of amino acid requirements in humans? The Journal of Nutrition, 134(6), 1558S-1565S. https:// doi.org/10.1093/jn/134.6.1558S

Haytowitz, D.B. and Matthews, R.H. (1983). Effect of cooking on nutritive retention of legumes. Cereal 
Food World, 28(6), 326-364.

Hao, W., Tian, P., Zheng, M., Wang, H. and Xu, C. (2020). Characteristics of proteolytic microorganisms and their effects on proteolysis in total mixed ration silages of soybean curd residue. Asian-Australasian Journal of Animal Sciences, 33(1), 100-110. https://doi.org/10.5713/ ajas. 18.0933

Hossain, S., Rashed, A., Sujan, B., Abdullah, A. and Michio, H. (2016). Proximate composition and fatty acid analysis of Lablab purpureus (L.) legume seed: implicates to both protein and essential fatty acid supplementation. SpringerPlus, 5, 1899. https:// doi.org/10.1186/s40064-016-3587-1

Ihekoronye, A.I. and Ngoddy, P.O. (1985). Integrated Food Science and Technology for the Tropics, p. 283. Ibadan, Nigeria: University of Ibadan Press.

Kakade, M.L., Rackis, J.J, McGhee, J.E. and Puski, G. (1974). Determination of trypsin inhibitor activity of soy products: a collaborative analysis of an improved procedure. Cereal Chemistry, 51(3), 376-382.

Khalil, M.M. (2001). Effect of soaking, germination, autoclaving and cooking on the chemical and biological value of guar compared with faba bean. Molecular Nutrition and Food Research, 45(4), 246250. https://doi.org/10.1002/1521-3803(20010801) 45:4<246::AID-FOOD246>3.0.CO;2-F

Lambrides, C.J. and Godwin, I.D. (2006). Mungbean. In Chittarajan, K. Genome Mapping and Molecular Breeding in Plants. Vol. 3, p. 69-90. USA: Springer.

Makkar, P.S.H. and Goodchild. (1996). Quantification of Tannins. A Laboratory Manual. Aleppo, Syria: International Center for Agriculture Research.

Malomo, O., Alamu, A.E. and Oluwajoba, S.O. (2013). Effect of processing on the total amino acid profile of maize and cowpea grains. Journal of Advanced Laboratory Research in Biology, 4(2), 77-82.

Mansour, E.H. and El-Adawy. (1994). Nutritional potential and functional properties of heat-treated and germinated fenugreek seeds. LWT - Food Science and Technology, 27(6), 568-572. https:// doi.org/10.1006/fstl.1994.1111

Motgotsi, K.K. (2006). Vigna radiata (L). R. Wilczek. In Brink, M. and Belays, G. (Eds.). PROTA 1: Cereals, and pulses/cereals et legumes secs. Wageningen, Netherlands: PROTA.

Mubarak, A.E. (2005). Nutritional composition and antinutritional factors of mung bean seeds (Phaseolus aureus) as affected by some home traditional processing. Food Chemistry, 89(4), 489-495. https:// doi.org/10.1016/j.foodchem.2004.01.007

Ndidi, U.S., Unekwu, C., Asegame, I.A., Yakubu, O.B.,
Mankilik, M. and Adamu, Z. (2014). Effects of Processing (Boiling and Roasting) on the Nutritional and Antinutritional Properties of Bambara Groundnuts (Vigna subterranea [L.] Verdc.) from Southern Kaduna, Nigeria. Journal of Food Processing, 2014, 472129. https:// doi.org/10.1155/2014/472129

Nugraheni, M., Purwanti, S. and Ekawatiningsih, P. (2020). Nutrient and sensory analysis of analog rice made with arrowroot (Maranta arundinaceae) flour, germinated red kidney bean (Phaseolus vulgaris L) flour, germinated white sorghum flour, and sago starch. Food Research, 4(6), 2241-2246. https:// doi.org/10.26656/fr.2017.4(6).269

Oniofiok, N., Nnayelugo, D.O. and Ukwondi, B.E. (1996). Usage patterns and contributions of fermented foods to the nutrient intake of low-income households in Emene, Nigeria. Plant Foods for Human Nutrition, 49(3), 199-211. https:// doi.org/10.1007/BF01093216

Oyarekua, M.A. (2011). Biochemical and Microbiological changes during the production of fermented pigeon pea (Cajanus cajan) flour. African Journal of Food Science and Technology, 2, 223-231.

Reeds, P.J. (2000). Dispensable and indispensable amino acids for humans. The Journal of Nutrition, 130(7), 1835S-1840S. jn/130.7.1835S

Salama, A.M. and Ragab, G.H. (1997). Composition of conventional and microwave cooking of kidney beans and carrot in relation to chemical composition, nutritive value and sensory characteristics. Journal of Home Economics-Menoufia University, 7, 213225.

Vijayakumari, P., Siddhuraju, P., Pugalenthi, M. and Janardhanan, K. (1998). Effect of soaking and heat processing on the levels of antinutrients and digestible proteins in seeds of Vigna sinensis. Food Chemistry, 63(2), 259-264. https://doi.org/10.1016/ S0308-8146(97)00207-0

Wang, N., Lewis, M.J., Brennan, J.G. and Westby, A. (1997). Effects of processing methods on nutrients and antinutritional factors in cowpea. Food Chemistry, 58(1-2), 59-68. https://doi.org/10.1016/ S0308-8146(96)00212-9

Wheeler, E.I. and Ferrel, R. (1971). A method for phytic acid determination in wheat and wheat fractions. Cereal Chemistry, 48, 312-316. 